\title{
Towards a "new" model of economic growth: empirical evidence from Romania's case
}

\author{
Ramona-Mihaela Matei ${ }^{1,}$, , Dumitru-Alexandru Bodislav ${ }^{2}$, Ioan Radu $^{1}$ \\ ${ }^{1}$ Faculty of Management, Bucharest University of Economic Studies, Bucharest, Romania \\ ${ }^{2}$ Faculty of Economics, Bucharest University of Economic Studies, Bucharest, Romania
}

\section{Email address:}

ramona.matei1982@gmail.com (R. Matei), alexandru.bodislav@infinitumgroup.com (D. A. Bodislav), iradu13@gmail.com (I. Radu)

\section{To cite this article:}

Ramona-Mihaela Matei, Dumitru-Alexandru Bodislav, Ioan Radu. Towards a "New" Model of Economic Growth: Empirical Evidence from Romania’s Case. International Journal of Business and Economics Research. Vol. 2, No. 5, 2013, pp. 91-97. doi: $10.11648 /$ j.jiber.20130205.11

\begin{abstract}
Economic growth and the policy for economic growth transformed starting with the end of World War II as a result of the desire to implement economic recovery and obtain economic and social prosperity. To achieve healthy (understood as durable and sustainable) economic growth real convergence is needed to catch up and grow at the European Union's standards. This paper presents the situation met in the Romanian market with the perspective of three economic models implemented on its case.
\end{abstract}

Keywords: Economic Growth, Economic Policy, Model, Sustainable Economic Growth, Economics

\section{Introduction}

The main example for benefits created by following the idea of economic growth are the ones given by the countries from the Far East that after World War II succeeded to create an environment friendly for social welfare growth and to satisfy their national interests, that were in line with the population's interests. The process for increasing life standards in the Far East were long term processes. The positive perception of economic growth is clear and correct if only there are some processes in favor of economic growth understood.

There are many ideas that could be extracted from studies that underline the fact that the classic model for economic growth which was used until the year 2000 was overused and overvalued much early than the year 2000 . There could be considered as the real moment of rupture or the moment when there was realized that a new paradigm is needed when the classic model for economic growth was surpassed by the complexity of the dot.com crisis from the 2000 - 2001 timeframe, but it could be designed as defaulted from other 3 characteristics:

- 1986: the development of financial derivatives on Wall Street (the first rupture);

- 1990: the development of the Internet as on open platform (the ARPANET - the second rupture);

- 1998: the abrogation of Glass-Steagall law, abrogation that permitted to unify special purpose banks in the actual too big to fail banking giants and using liquid assets under the form of high yield financial instruments (the third rupture).

This paper addresses two main objectives. The first objective is to highlight the evolutionary framework of economic growth models starting with the end of World War II to the present one in order to outline the context of the analysis of these models. The second objective aimed at achieving an empirical analysis of economic growth situation in Romania from the 1990-2011 period in order to reveal how this country's economy has evolved to a new model of economic growth and how the country's governance was executed in covergence with the three economic growth models reviewed and developed in the following pages, in the end concluding with the big picture on the global economic situation and its development to the near-future challenges.

\section{Theoretical Framework: Evolution of Economic Growth Models}

\subsection{The Traditional Model-the Classic Economic Growth Model}

The classic model for economic growth couldn't handle the complexity of newly created components [1]: Wall 
Street's derivability (economic marking of some components without real foundations: third degree services, services resulted from services that are founded on other services) and the network economy that reached global productivity, without boundaries and the 24 hours work day (the Internet came as a solution for some problems that weren't legally and commercially framed). In the year 2005 took place the Initial Public Offering for NASDAQ New York, which happened by the merger with the biggest worldwide electronic platform, Archipelago Exchange Chicago, this way there was transformed the model for local transaction into a global operations model with 24 hours work frame. The new approaches based on new principles and criteria, that were in line with the technological, economic, social and environmental transformations [2-10] are elements that set pressure on the actual economic growth model.

The concept of economic growth and the concept of economic policy for obtaining economic growth were created after World War II, but they suffer continuous changes because of the economic evolution that appeared at the beginning of this millennium, be it the dot.com crisis, be it the economic-financial-social crisis started in the year 2007. The new problems create the new hypothesis for sustainable approach of implementing economic growth.

Economic growth is a concept that appears to be ordinary, especially in recession, but not in the sustainable or healthy economic growth approach [1]. This idea was first established in an economic context better than two centuries ago, and was conceived as an approach on increasing productivity at company level (microeconomic logic). The actual path for economic growth was developed starting with the creation of the theory of economic growth in the $4^{\text {th }}$ decade of the $20^{\text {th }}$ century as a result/answer la the Great Depression from 1929 - 1933, showing this way the limits of a microeconomic approach of the macroeconomic reality.

What is economic growth? It could be described as a positive motion of some global economic values (GDP growth or income growth) on a longer period of time (economic growth isn't executed with a projection on the short run, because there are needed some year cycles to pass, it couldn't be considered as economic growth the yearly evolution). For a better shaping of the economic growth (1), the positive movement must be trended on the long run and not as a result of exogenous factors. Although it is based on the GDP growth, the approach must have a social approach in comparison with the GDP per capita and its increasing trend. The growth of welfare is a qualitative measure resulted as an effect of economic growth, but the concept of economic growth is based on quantitative and structural modifications that are resulted on medium and long term. Through the roll-over phenomenon we have to deal with an irreversible phenomenon, auto generated by the performances of production factors that maintain development.

\subsection{The Actual Model-the Durable Economic Growth Model}

How did it led to durable economic growth? During the reinterpretation of the theoretical approach as a result of the pressure created by the syncope from the 80 's there was realized the fact that these plans were needed to create the new economy, "the information economy", based on information technology that wasn't a component of the classical approach [1]. Practically, the new economy is based on the idea $[4,9,11]$ of the existence of some unconventional new resources without depletion (know-how and human capital's capacity for innovation).

The main asset under the influence of accelerated extensive and intensive development effect is nature (the holder of finite resources) fact that led to the acceleration of the scarcity effect of resources through an exponential growth of consumption of resources and to excessive exploitation that had as result the degradation of the environment $[8,10,12,13]$ that through the roll-over of the problem will lead on the long run to endangering economic growth and the impossibility of developing the society. To this issue there can be added the discrepancies on educational level, which create instability intra and international and make the catching up process between emergent economies and developed ones become harder or even impossible to fulfill.

Durable economic growth is based on its tridimensional development [14]:

1. Economic: based on investment in scientific research and information technology and stimulating the capacity for innovation of the human capital;

2. Social: reducing the disparities between different social groups (assuring equality of chances and access to education, culture, information and the possibility to create tangible welfare);

3. Ecological: logical exploitation, consumption and utilizing efficiency of resources leads to obtaining a long term effect that leads to durable economic growth for the long run, this way offering repletion time for the used resource, and prolonging the used resources life cycle.

A new evolution in the domain of human capital management [1] is represented by rediscovering hard skills (the technical component) [5], but in line with minor support from soft skills (the human component) [4, 11]. The production factors aren't the main element of obtained growth, but the human being (executioner and beneficiary of the process of durable economic growth), that is why is needed that the human being must be handled with social justice and equity. Durable economic growth is based on the elements developed in beginning of this paper, the market or the government [15], because they represent the backbone that sustains the needed structure for positive functioning and evolution [1]. It is also representative for maintaining and increasing the potential of an economy and of social welfare (it is a system for fighting against poverty), the GDP 
per capita is understood as the main indicator for observing the ascendant trend in the evolution of a state.

\subsection{The New Model- the Sustainable Economic Growth Model}

According to Simon Kuznets, economic growth also consists of increasing the capacity of a country to deliver more and more different economic goods through cutting edge technologies for production and institutional and ideological adaptability [16], this way showing the macroeconomic nature of the concept [17] (on social, economic and ecological level) [3, 6,10,13].

Economic growth is based on the direct relation between resource input and production and GDP output, and the difference measures the efficiency in the growth process, the rational consumption of allocated resources on industry sectors and the efficiency in qualitative distribution and redistribution in the domains that excel and represent a competitive/comparative advantage against other countries [1].

As a reform of the durable economic growth there is the sustainable economic growth, chosen as a tie from the present moment in which the Great Recession is founded on the durable economic growth model. Sustainable economic growth is based on obtaining economic growth by approaching a national or union economic system through the same mechanisms and levers found in a corporation, but shifted at the level of national work levers. This way an ultra-efficient approach on pollution and social security issues can be obtained, and as main innovation there is achieving long term economic stability and the progress of social welfare, assuring harmonic welfare between the economy, society, nature and technology.

Sustainable economic growth set under the globalization's pressure [2] the idea of the network economy, having as positive externalities obtaining access at new markets, especially the access to new clients (bigger demand, higher production), occupational modeling (decreasing unemployment in countries with a work force able to work on a wage below average of the same sector's wage in the host country or based on the outsourcing of some services in other countries, the host country having a wage cost lower than the paid wage in the home country of the outsourced service or product). A check point for the imported flow from the corporate framework is represented by keeping normal limits that do not harm the work force migration, the economic, social, educational disparities and the resources that are distributed equitable and efficient.

\section{The Model of Economic Growth in Romania's Case}

The situation of the Romanian economy in comparison with what the economy should be like will be presented from now on to stress the main axes followed to obtain economic growth and to underline the need for a more market oriented state governance that can be created by implementing on the medium and long term some basic principles from the corporate governance domain [18].

\subsection{Investments in Human Capital}

The private sector was the promoter of investments in human capital through trainings and academic or professional specialization with an average of $2 \%$ of the available annual salaries' pool, landing on the last place of the EU27 hierarchy. For comparison we have Ireland that has as average investment in training per employee a percentage of $32 \%$ per salary, per year, but starting from 2007 the percentage remains constant, but the real salary is decreasing. This hierarchy is completed by professional reconversion and re-qualifying the work force through projects created in private-public partnership financed from dedicated European funds.

\subsection{Investments in Physical Capital}

Starting with the year 1990 the state governance had as main purpose the restoration and the development of road infrastructure, but the political clientele led to the inefficiency of the economic growth' programs, fact that happened with the support of the political power, despite their political ideologies. Attracting foreign investors in Romania led to the development of advanced telecommunication' systems, to which there are added the production facilities implemented and deployed by Renault at Dacia and other investments that boosted the catching up process of Romania.

\subsection{Maintaining the Pace with Technological Changes}

After the year 2000, the non-speculative privatizations took the lead in the overall privatization pool and this healthy privatization boosted the imports of large capacity production technologies and the high efficiency obtained through the knowledge (management) attracted from the corporate governance' process [18].

For all of the above processes we have as support the evolution of foreign investment in Romania in the period 1999 - 2011 deployed at holistic level, at the annual rate and as of capital contribution or as a secondary flow. In the development of these elements it can be observed the fact that the trend had an inflection point in the year 2002 when it had fallen sharply as an answer to the political situation from that moment and as an answer to the economic situation that was imported from the international level in a transparent way. In the period of economic expansion the absorption of the foreign direct investment (FDI) was described by an ascendant trend, with a growing ratio from year to year starting with the year 2002 until the third quarter of the year 2007. After this period the instability on the global financial markets was present and created chaotic capital movements (from subsidiaries to their corporate headquarters) and the FDI started decreasing in ratio, the year 2008 was at a level under the year 2005, and the following years 2009 and 2011 
at a level under the year 1999.

Table 1. The structure of Foreign Direct Investments in Romania, 1999 2011

\begin{tabular}{lllll}
\hline Year Total FDI & $\begin{array}{l}\text { Annual } \\
\text { FDI rate }\end{array}$ & $\begin{array}{l}\text { FDI } \\
\text { capital }\end{array}$ & main & $\begin{array}{l}\text { FDI secondary } \\
\text { capital }\end{array}$ \\
\hline $\mathbf{2 0 1 1}$ & 53203.60 & 618.30 & 35925.60 & 17278.00 \\
$\mathbf{2 0 1 0}$ & 52585.30 & 2600.80 & 35529.00 & 17056.30 \\
$\mathbf{2 0 0 9}$ & 49984.50 & 1187.80 & 35600.20 & 14384.30 \\
$\mathbf{2 0 0 8}$ & 48796.70 & 6026.00 & 34891.00 & 13905.70 \\
$\mathbf{2 0 0 7}$ & 42770.70 & 8258.70 & 31501.00 & 11269.70 \\
$\mathbf{2 0 0 6}$ & 34512.00 & 12628.00 & 27016.00 & 7496.00 \\
$\mathbf{2 0 0 5}$ & 21884.00 & 6844.00 & 17489.00 & 4395.00 \\
$\mathbf{2 0 0 4}$ & 15040.00 & 5379.00 & 12007.00 & 3033.00 \\
$\mathbf{2 0 0 3}$ & 9661.00 & 2179.00 & 7092.00 & 2569.00 \\
$\mathbf{2 0 0 2}$ & 7482.00 & -1174.00 & 5530.00 & 1952.00 \\
$\mathbf{2 0 0 1}$ & 8656.00 & 1690.34 & 8218.66 & 437.34 \\
$\mathbf{2 0 0 0}$ & 6965.66 & 1519.14 & 6696.06 & 269.60 \\
$\mathbf{1 9 9 9}$ & 5446.52 & & 5275.16 & 171.36 \\
\hline & & & & \\
\hline
\end{tabular}

Million Euro at the parity for the year 1999

Source: the National Bank of Romania (NBR) [19]

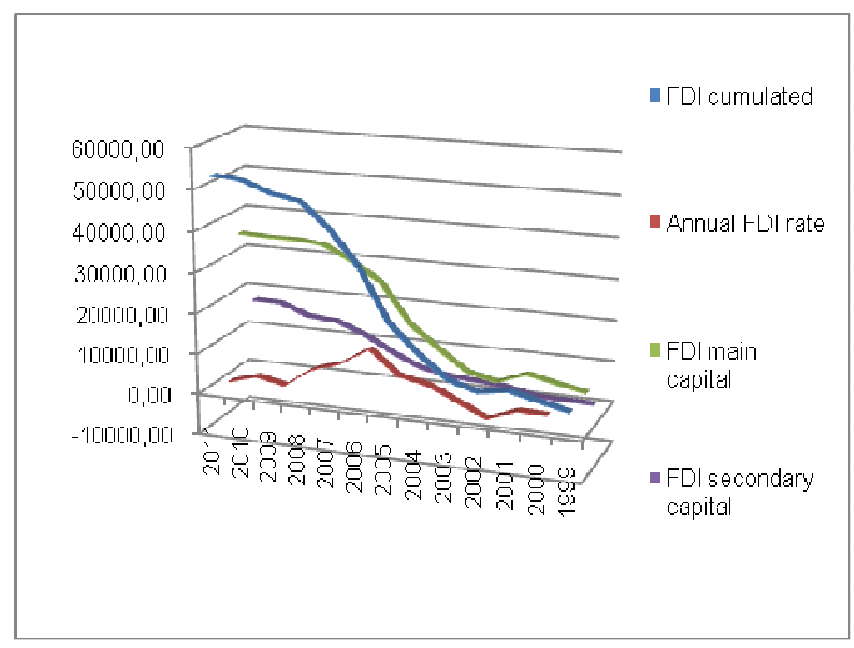

Fig. 1. The Evolution of FDI in Romania, 1999 - 2011

\subsection{The Institutional Environment Designed on Satisfying Needs and the Economic Situation}

The adaptation of the governmental, legislative and administrative environment at the economic situation and adopting the imposed practices at the European level have inserted Romania on the path to streamline the bureaucratic system to achieve the minimum standards imposed for the accession in the European Union and correlating it with the Community's systems of deploying the programs for economic and social development and economic growth.

\subsection{The Optimal Role for the Government}

On the path for fulfilling the population's necessities and to adapt at the economic situation of the state governance has as main purpose keeping and pushing competitiveness to higher grounds at internal level and at international level, followed by the implementation of reforms to decrease social disparities (on this section of the economy, Romania didn't achieved the creation of the middle class that represents almost $8 \%$ from total population and this fact stresses the unsustainable economic development and the social pressure created by inequality and social inequality).

On budgetary instruments, Romania had a stable positive evolution in the $1990-2008$ timeframe, but when the crisis was installed it couldn't be maintained, because of the international pressure and because of the positional reorganization regarding the economic crisis (an observable phenomenon through the evolution of the country's ratings).

Starting from the budgetary instruments Romania wasn't correlated between the economic cycles and the used fiscal model that was correlated with the work inefficiencies that were based on the fact that the fiscal strategy of Romania was in continuous sudden changes that took the country out from the list of attractive countries (stable) for investments [18].

Before entering the qualitative evaluation based on quantitative indicators we must present the convergence criteria of the Maastricht Treaty:

- The budgetary deficit of maximum 3\% from GDP;

- The public debt of maximum $60 \%$ from GDP;

- The inflation rate must be with maximum 1.5 percentage points above the average of the first three states with the lowest inflation rate;

- The interest rate on the long term must be with maximum 2 percentage points above the average of the first three states with the most stable prices;

- The exchange rate must be in the $+/-15 \%$ range for the last two years.

At the spending' level, these were designed in an inefficient way from the beginning of the crisis, creating large deficits, above the level ratified through the Maastricht Treaty, but the whole Eurozone couldn't maintain itself under the 3\% level. The budgetary deficit of Romania after the establishment of the crisis, increased as a result of the government's incapacity to reorganize the spending' level due to the actual economic requirements, as a result the 2008 -2010 period represented a dangerous slippage from the $3 \%$ targeted level for the deficit with a maximum $8 \%$ deficit in 2010 and with a spectacular recovery in 2011 in the target of $4,4 \%$ imposed by the International Monetary Fund (who lent to the Romanian government 13,4 billion dollars), Romania reaching in the year 2011 a level of $4,35 \%$ for the budgetary deficit and the short term objective to fulfill the convergence criteria imposed through the Maastricht Treaty. 
Table 2. The evolution of the Budgetary Deficit of Romania in the $1991-$ 2011 timeframe

\begin{tabular}{lcccccc}
\hline Year & $\mathbf{1 9 9 1}$ & $\mathbf{1 9 9 3}$ & $\mathbf{1 9 9 5}$ & $\mathbf{1 9 9 7}$ & $\mathbf{1 9 9 9}$ & $\mathbf{2 0 0 0}$ \\
\hline Budgetary deficit & -1.5 & -0.1 & -2.6 & -3.6 & -2 & -3.7 \\
$\mathbf{2 0 0 2}$ & $\mathbf{2 0 0 4}$ & $\mathbf{2 0 0 6}$ & $\mathbf{2 0 0 8}$ & $\mathbf{2 0 0 9}$ & $\mathbf{2 0 1 0}$ & $\mathbf{2 0 1 1}$ \\
-2.6 & -1.1 & -1.7 & -5.4 & -7.2 & -8 & -4.35 \\
\hline
\end{tabular}

Source: NBR and INSSE [19, 20]

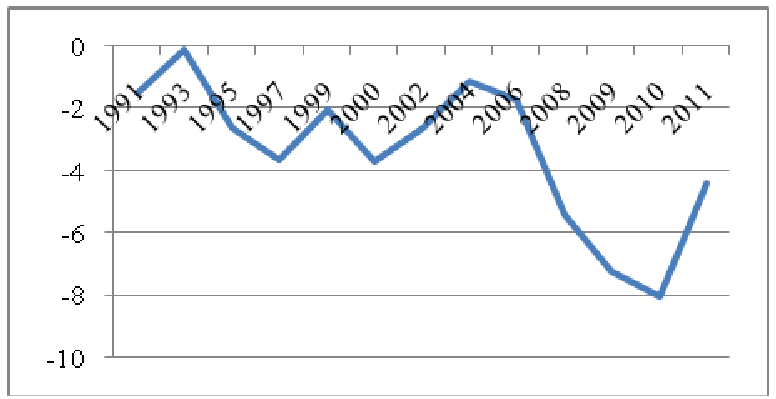

Fig. 2. The evolution of the Budgetary Deficit of Romania in the $1991-$ 2011 timeframe (\%)

Regarding the public debt it can be brought to the spotlight the development of the public debt until the Great Recession was triggered in 2007. Until 2008 it didn't had any importance because the FDI that entered the country created businesses that reached incomes that brought money to the budget through taxes and decreased the unemployment rate. From the moment Romania's economy felt the systemic recession and from the fact that it was unprotected (protection should be understood as a proactive state governance measure or as a fast response to the newly created situation, that in time became the new normal) or, the deployment of governance based on "the new normal" was done through income cuts and austerity measures that created the situation that any government is obliged to prevent because it can perturb their activity. Romania's public debt evolved as presented in the following figure:

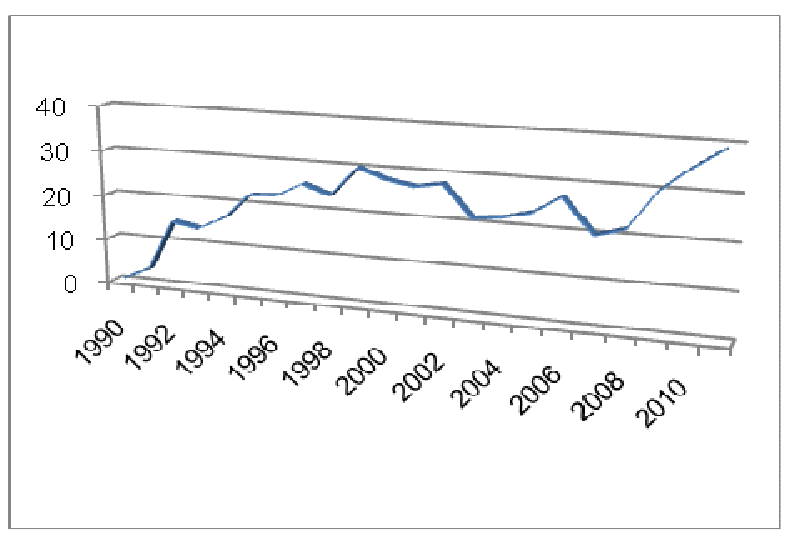

Fig. 3. The Evolution of the Public Debt of Romania, 1990 - 2011

It can be observed from figure 3 that Romania is situated these days under the maximum level ratified in the
Maastricht Treaty' convergence criteria of $60 \%$ from the GDP, for the year 2011 the public debt to GDP ratio was of $39 \%$, but with an increasing trend (from $21,7 \%$ in 2008 to $39 \%$ in 2011), and if there is added the fact that the rollover of the debt created through loans from the International Monetary Fund and the European Union it can stress a future syncope if the Romanian economy doesn't perform as planned.

The Gross Domestic Product had an evolution in the 1990 - 2011 timeframe that was of adjustment, establishing an ascendant trend, accelerated growth (based on transition and the catching up phenomenon) and of hard landing as a result of the installed global economic crisis and because of the effect of contagion that affected Romania [18].

To stress the influence of the economic crisis and the comparison with the global situational development there were selected for comparison starting from 2002 until 2010 the macroeconomic results of Romania compared with EU27 and with the main engine of the global economy, the United States of America.

Table 3. The global Evolution of Romania's GDP/population compared with EU27, USA and the lost potential (the output gap)

\begin{tabular}{|c|c|c|c|c|c|}
\hline Variable/date & 2002 & 2003 & 2004 & 2005 & 2006 \\
\hline GDP/pop. EU27 & 100 & 100 & 100 & 100 & 100 \\
\hline GDP/pop. USA & 154 & 156 & 157 & 159 & 154 \\
\hline $\begin{array}{l}\text { GDP/pop. Romania } \\
\text { compared with EU } 27\end{array}$ & 29 & 31 & 34 & 35 & 38 \\
\hline $\begin{array}{l}\text { Output Gap for } \\
\text { Romania }\end{array}$ & -0.48 & -0.97 & 1.04 & -1.09 & -0.81 \\
\hline Variable/date & 2007 & 2008 & 2009 & 2010 & \\
\hline GDP/pop. EU27 & 100 & 100 & 100 & 100 & \\
\hline GDP/pop. USA & 151 & 147 & 145 & 148 & \\
\hline $\begin{array}{l}\text { GDP/pop. Romania } \\
\text { compared with EU27 }\end{array}$ & 42 & 47 & 47 & 46 & \\
\hline $\begin{array}{l}\text { Output Gap for } \\
\text { Romania }\end{array}$ & 2.17 & 6.2 & -2.95 & -3.46 & \\
\hline
\end{tabular}

Source: for the GDP/population Eurostat database [21] and for the Output Gap the article: „Re-modeling the Romanian Fiscal Policy under the Terms of the Economic Crisis" [22]

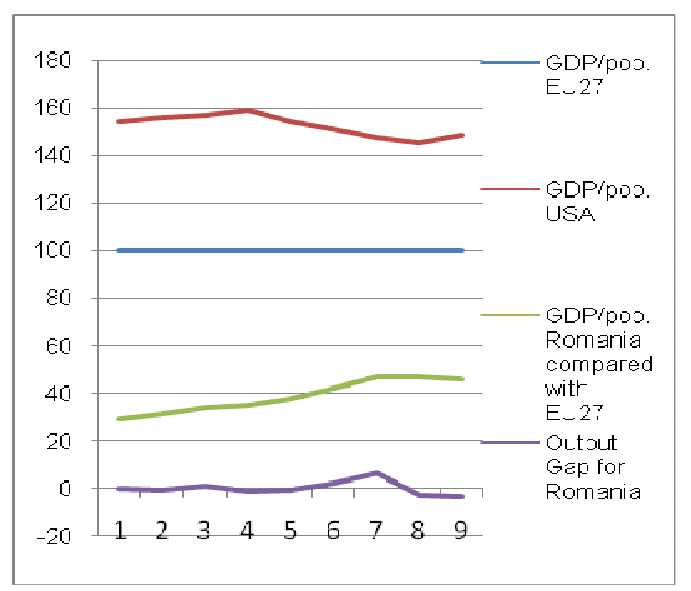

Fig. 4. The Global Evolution of Romania $2002-2010$ 
There were selected as common ground the values of EU27 and USA to compare with Romania, because Romania has as main target catching up the European Union. The catching up process was started with the transition process from the $1990-2000$ period and was followed by a buffer process between the transition and the catching up process from the period $2000-2002$ and continued with the accession process started in 2000, but with real implementation starting from 2002 when it reached the accession in the Eurozone milestone from the monetary vantage point.

\section{Results and Discussion}

To achieve healthy (understood as durable and sustainable) economic growth real convergence is needed to catch up and grow at the European Union's standards. It is observed that the Maastricht Treaty has as foundation the same objectives with the economic growth policy and fulfilling the convergence criteria that are equivalent with fulfilling the intermediary objectives in reaching the final goal: durable or sustainable economic growth.

As an ally of the catching up process there is the globalization phenomenon that allows through the improvement of the global flow reaching the flotation level that can ease economic development and will observe the adoption and adaption of a future new economic model, designed to achieve the development of a healthy state, a competitive market and continuous corporate deployment, by setting as global objective for economic welfare obtaining sustainable economic growth founded on real systems for economic implementation and execution.

From what we could see an the research done above the fact the three models for economic growth evolved in Romania, but without reaching a consensus in implementation and with results that aren't concludent for the first two models, but the one regarding sustainable economic growth we can stress that the economy is gradually converging to this near-future state and starting the year 2014, Romania's economy will try to develop itself into the best suitable option of an open economy prepared for the 21 st century.

This research paper was targeted to underline where is Romania today, after 24 years of muddling through the tranzition between communism and market economy and the exogenus pressure created by the actual economic crisis that developed this assymetric and unstable economic environment that needs a new solution, a hybrid model that uses proactive guidance programs to connect the actual economic model to the sustainable one and confront proactively the near-future crisis, the one based on growing deficits and basic foods supply inneficiency, crisis that will collide above the Kondratiev economic cycle (the link between the 1929-1933 and 2007-2014 crises) and could be considered as the super-cycle, the one based on human-economic cyclicity or the developed need for a new paradigm that will create a 180 degrees change for the actual social, neo-liberal and capitalist system, which will replace the paradigm of the First Modernity, and create not an improvement but a totally new path that could drive us to a stable and proactive environment for the next one and a half century until a future new paradigm will be needed to be created.

\section{Acknowledgements}

This work was cofinaced from the European Social Fund through Sectorial Operational Programme Human Resources Development 2007-2013; project number POSDRU/107/1.5/S/77213 „Ph.D. for a career in interdisciplinary economic research at the European standards".

\section{References}

[1] D.A. Bodislav, The New Economy: Efficiency, equity and sustainable economic growth, Quality Review - Access to Success, 13( S1), pp. 21-29, 2012

[2] L. Oxelheim, Globalization, transparency and economic growth: The vulnerability of Chinese firms to macroeconomic shocks, Journal of Asian Economics.21(1), pp. $66-75,2010$

[3] S. Boakye, Theory of social transformation, political transition and economic growth, Economic Systems, 36(3), pp. 411-425, 2012

[4] C. Mattalia, Human capital accumulation in R\&D-based growth models, Economic Modelling, 29(3), pp. 601-609, 2012

[5] K. M. Vu, ICT as a source of economic growth in the information age: Empirical evidence from the 1996-2005 period,Telecommunications Policy, 35( 4), pp. 357-372, 2011

[6] C. Minoiu and S. G. Reddy, Development aid and economic growth: A positive long-run relation, The Quarterly Review of Economics and Finance, 50(1), pp.27-39, 2010

[7] Ph. LeBel, The role of creative innovation in economic growth: Some international comparisons, Journal of Asian Economics, 19(4), pp.334-347, 2008

[8] V. Costantini and S. Monni, Environment, human development and economic growth, Ecological Economics, 64( 4), pp. 867-880, 2008

[9] İ.S. Akçomak and B. Weel, Social capital, innovation and growth: Evidence from Europe, European Economic Review, 53( 5), pp. 544-567, 2009

[10] J.M. Reilly, Green growth and the efficient use of natural resources, Energy Economics, 34(1), 2012

[11] B. Warr and R.U. Ayres, Useful work and information as drivers of economic growth, Ecological Economics, 73(15), pp. 93-102, 2012

[12] S. Silva and I. Soares and O. Afonso, Economic growth and polluting resources: Market equilibrium and optimal policies, Economic Modelling, 30, pp. 825-834, 2013 
[13] K.G.Mäler, Economic Growth and the Environment, Encyclopedia of Biodiversity (Second Edition), pp.25-30, 2013

[14] C. Angelescu and I. Stanescu, The Policy for Economic Growth, Economica Publishing, Bucharest, 2004

[15] C.H. Knutsen, Democracy, State Capacity, and Economic Growth, World Development, 43, pp. 1-18, 2013

[16] K. Muler, Modern Economic Growth: Rate, Structure and Spread (Simon Kuznets), Ludwig Maximilians Universitat, Munchen, 2008

[17] V.Ruttan and Y. Hayami, Can Economic Growth Be Sustained?, Oxford University Press, New York, 2011

[18] D.A. Bodislav, The Catching Up Process - A Review of Romania's Case, Metalurgia International,6(XVII), pp. $125-130,2012$
[19] National Bank of Romania. Interactive database. http://www.bnro.ro/Interactive-database-1107.aspx,March 2013

[20] Romanian National Institue of Statistics. Tempo Online Database.https://statistici.insse.ro/shop/?lang=enhttps://statis tici.insse.ro/shop/?lang=en, March 2013

[21] EuropeanComission.Eurostat.Statistics.http://epp.eurostat.ec .europa.eu/portal/page/portal/statistics/search database, March 2013

[22] A. Socol and D. Mantescu, Re-modeling the Romanian Fiscal Policy under the Terms of the Economic Crisis, Theoretical and Applied Economics, 18 (1), pp.111 - 120, 2011 